\title{
POPULATION GROWTH AND JOB CREATION IN TIMOR-LESTE
}

\author{
Mats Lundahl \\ Fredrik Sjöholm \\ Working Paper 226 \\ June 2006
}




\title{
POPULATION GROWTH AND JOB CREATION IN TIMOR-LESTE
}

\author{
Mats Lundahl \\ Fredrik Sjöholm* \\ Stockholm School of Economics
}

\begin{abstract}
Timor-Leste began its independence as one of the poorest nations in the world. Substantial progress has been made thereafter but the challenges for future development are numerous. High population growth and modest growth of GDP means that per capita income is declining and that the extent of poverty is increasing. For this situation to change, income opportunities other than those provided by subsistence agriculture are needed. Considering the low level of education and the keen competition for skilled personnel this, however, is difficult. So far, it seems that most skilled workers are being absorbed by the public sector and that this is pushing up the already high skilled wage level. That, in turn, affects the competitiveness of the private sector negatively and acts as an obstacle to the creation of employment opportunities outside agriculture.
\end{abstract}

Keywords: Timor-Leste; Job Creation; Development; Industry JEL codes: O10; O14; O15

\footnotetext{
${ }^{*}$ Corresponding Author: Stockholm School of Economics. Box 6501, S-113 83 Stockholm, Sweden. Phone +46 873693 63, Fax + 4683130 17, email freddrik.sjoholm@hhs.se
} 


\section{INTRODUCTION}

Timor-Leste is the youngest nation in the world. The birth of the country was both protracted and difficult. After twenty-five years of Indonesian occupation, the referendum held in 1999, which indicated that an overwhelming majority of the Timorese were in favor of independence, ended in widespread human and material destruction. Timor-Leste, already one of the poorest countries on earth, lost at least one-fourth of its GDP and the production apparatus was in shambles (e.g. Shoesmith, 2003, pp. 233-34).

The first few years of independence have been characterized by strong efforts to put institutions in place with the help of foreign assistance and by the launching of various programs aiming at poverty reduction. Considerable progress has been accomplished in vital areas such as health provision (Lundahl and Sjöholm, 2005). Moreover, the Timorese economy has grown during recent years, although mainly as a result of the recovery from the 1999 destruction. Finally, large and sudden inflows of oil and gas revenues have changed the development constraint from financial, to one where less than actual public revenues can be spent because of lack of administrative capacity.

Despite this progress, it is clear that the challenges ahead are formidable and that new problems are emerging. Timor-Leste lacks a modern private sector and the economy consists mainly of subsistence agriculture. Moreover, an unparalleled and increasing birth rate makes for a population growth so high that it will put considerable strain on the subsistence sector where diminishing returns to labor are strong. As a result, even though Timor-Leste's economy has been growing, income per capita seems to have declined during the latest two years. To lift broad segments of the population out of poverty requires job creation in a modern sector. However, a very low level of education makes it difficult to expand industrial production simultaneously with the public institutions. Skilled labor is in very scarce supply 
and the educated tend to be absorbed by the public sector. The private sector is therefore facing a shortage of skilled labor.

The present essay analyses the job creation problem in Timor-Leste. We start by an account of the population growth issue. This is followed by a discussion of the need for job creation in the modern sector, and by an analysis of the constraints to modern sector development. The essay ends with some concluding remarks.

\section{POPULATION GROWTH}

Three years after independence, the economy of Timor-Leste remains both fragile and vulnerable. The recovery that took place in the wake of the destructions in 1999 could not be sustained in 2002 and 2003, and real non-oil GDP fell both years, with 6.7 and 6.2 percent, respectively. Once the 'easy' phase of reconstruction came to an end, moving further ahead proved difficult. The latest available figures tend to indicate positive growth in both 2004 (1.8 percent) and 2005 (2.5 percent) (International Monetary Fund, 2005, p. 31).

These figures, however, are not sufficient to make up for the growth of the Timorese population. When the results of the 2003 Demographic and Health Survey became available they contained a very fundamental finding: the fertility rate in Timor-Leste is the highest in the world with 7.8 children per woman in childbearing age (over the period 200103), far higher than the figures for other Southeast Asian countries (the second highest figure is that for Laos: 4.7). Worse yet, the figure appears to be on the rise. During the 12 months preceding the survey it was as high as 8.3 (Ministry of Health et al., 2004, p. 6). Translated into population growth terms this implies that the Timorese population every year increases by 3 percent (World Bank, 2005a, p. 6), which in turn means that real per capita income must be falling and presumably also that the extent of poverty is increasing over time. A population growth figure of 3 percent per annum implies that the population will double in 17 years. It is 
hence obvious that the high fertility rate is a ticking time bomb from the point of view of poverty and poverty eradication. If anything, things will become worse over the next two decades unless something is done to seriously address the problem.

Recent studies of Indonesia indicate that access to family planning may have drastic effects on fertility. '... moving from an environment of no family planning programs to a full complement of family planning programs being in existence since before the woman was born would reduce fertility by almost one child per woman’ (Angeles, Guilkey and Mroz, 2005, p. 195). Unfortunately, the prevailing attitudes in Timor-Leste towards family planning appear to imply that the high rate of population growth will continue in the foreseeable future. The fertility rate did not vary across subgroups among the women between 20 and 35, and education did not matter either. Higher wealth, on the other hand, led to a small reduction (from 8.1 among the poorest households to 6.9 in the wealthiest). Also, the median age for the first birth appears to be declining: over 24 years for women over 39, 22 for those between 30 and 39 and 21 for those from 20 to 29. Timorese women express a strong desire for many children. Their desired family sizes were the highest ever recorded in any demographic and health survey in the world. Only 17 percent of the women wanted no more children, the same figure as the one for the population in general. A mere 13 percent of the married women wanted access to family planning devices, however, not in order to limit the number of children (only 3 percent) but to space births properly (10 percent). Altogether only 75 percent of the total demand for family planning was met, and over 60 percent of the women and 70 percent of the men were completely ignorant about possible family planning methods. A mere 10 percent of the women used contraceptives (Ministry of Health et al., 2004, pp. 6-7).

Family planning is a difficult subject in Timor-Leste. Especially in the countryside, having many children is a sign of wealth, since the children can work in agriculture. The high birth rate was a concern for the Indonesian authorities in the 1970s and 
1980s and it is possible that in later years this has been counterproductive, with common people sensing a hidden agenda behind the insistence on fewer children. Also, the Catholic church is firmly against birth control and it is capable of quickly mobilizing large numbers of supporters. This was demonstrated in April 2005 when there were thousands of people in street demonstrations for three weeks in Dili, demanding that Prime Minister Mari Alkatiri resign because of the government's decision to drop mandatory religious education from the national school curriculum. Even if the influence of the church could somehow be neutralized, many observers feel that the problem would remain, since the prevailing attitudes towards family planning are very deeply rooted, as revealed by the Demographic and Health Survey.

A national policy for family planning is, however, now in place and has been approved by the council of ministers. The government will work closely with the church in the implementation. The idea is based on the concept of conscious parenthood. Prospective parents are to make decisions about the number of children. Regardless of their religious background the government is under obligation to provide the available information about methods for family planning, and equipped with this information, the citizens can make informed choices (Interview with Minister of Health, Rui Maria de Araújo, 23 August 2005).

\section{THE EMPLOYMENT ISSUE}

The strong population growth puts severe strain on the labor market and it can easily result in high un- and underemployment rates. Defining employment and unemployment is a difficult task in the Timorese context. The easiest way is by taking the distinction between the formal and the informal sector as the point of departure. In the latter, demand and supply balance in the sense that most people are their own bosses or work within the framework of the family economy. In this segment of the labor market no open employment will hence arise, because nobody can afford to be without a job. Instead, the problem is one of low productivity and 
incomes. The employment problem is a poverty problem. Virtually the entire Timorese economy in 2002 may be classified as informal. The upper limit for the formal sector could be drawn around 22,000 employees: the public administration, the NGOs and some foreign companies, out of a total labor force of 310,000. To the latter figure some 22,000 entrants in the labor market will be added each year, people who in their majority must be absorbed by informal economic activities if they are not to become openly unemployed (UNDP, 2002, pp. 17-18).

Employment statistics after 1999 are not good. It is estimated that in 1998 about three-fourths of those in the labor force made their living in agriculture, about 9 percent were found in public administration, less than 7 percent worked in the private sector or in NGOs, and an estimated 6 percent were openly unemployed. Three years later the share of openly unemployed had increased to almost 17 percent, while employment in public administration had fallen substantially, as a result of conscious trimming. Employment in the private sector had also been somewhat reduced, but not too much, because of the existence of a number of public employment projects there. Agriculture continued to serve as the sink in the labor market with almost 74 percent of the total labor force (Planning Commsssion, 2002, p. 22).

Growth is intimately linked to employment. The government has set a growth target of GDP of 6 percent per annum in the medium term (until 2009), to come to grips with the employment problem. According to the IMF, however, 'under current policies the authorities' medium-term growth objective of 6 percent will be difficult to achieve in light of continued difficulties in budget execution, tapering off donor activity, and an incomplete legislative and regulatory framework needed to attract private investment' (International Monetary Fund, 2005, p. 13).

Timorese employment statistics were no better in 2005 than in 2002, but one safe conclusion is that urban youths who are just entering the labor market are a vulnerable 
group, with an estimated unemployment rate of 43 percent, against 20 percent for urban areas on average (World Bank, 2005a, p. 4). Needless to say, both figures are very high and they point directly to the need for expanding the urban sector. Each year some 20,000 new entrants are added to the labor force (International Monetary Fund, 2005, p. 13).

The oil and gas sector will provide revenue but it will not provide any jobs. The IMF estimates that a growth rate in the order of 7 percent per annum is needed in the non-oil sector for enough jobs to be created to avoid a rise in unemployment (International Monetary Fund, 2005, p. 13). Putting more people into agriculture will not solve the problem, because diminishing returns to labor will set in, in a sector where productivity and incomes are already low. This, in turn, calls directly for an extension of the non-oil, non-agricultural sector. At the present stage of development in Timor-Leste, in practice no such sector exists, except for the public administration and some service establishments in Dili, i.e. the sector must be created.

\section{DEVELOPING A MODERN PRIVATE SECTOR}

Unless a modern sector is developed in Timor-Leste, the rapidly expanding population can hardly be absorbed in productive activities. The country, however, had no industrial sector at the eve of independence. Excepting the government bureaucracy, there was in fact not much of a modern sector at all. The money that had been flowing into the country from international donors and investors had been directed mainly to 'the service sector of the economy in Dili, providing retail, bar, restaurant, hotel, vehicle rental and telecommunication services. Other foreign investments controlled by skilled foreign workers are directly servicing the UNTAET reconstruction program’ (Planning Commission, 2002, p. 91). ${ }^{1}$ It was hardly a coincidence that neither the book edited by Hal Hill and João Saldanha on Timorese development challeges published in 2001 (Hill and Saldanha, 2001) nor the report prepared

\footnotetext{
${ }^{1}$ Most new investments were undertaken by Timorese citizens, however, no less than 82 percent of all ventures according to government figures. No value estimates were available (Planning Commssion, 2002a, p. 91).
} 
by the World Bank the following year (World Bank, 2002) had anything to say about industrial development. There was simply nothing to write about. The State of the Nation Report was vague as well on the issue of industrial development (Planning Commission, 2002, p. 91):

\begin{abstract}
Although much of the F[oreign] $\mathrm{D}$ [irect] $\mathrm{I}$ [nvestment] that has occurred so far has largely been in support of UN operations and personnel, there has also been considerable longer-term FDI in hotel structures, bottled drinking water production plants, and warehousing. Although no data is available separating foreign from domestic investment by sector, anecdotal evidence suggests that there is a small but increasing level of investment in small manufacturing operations, for example in coffee processing and packaging, and in the construction industry.
\end{abstract}

The existing support structures had been destroyed during the 1999 violence: buildings, power generation, telecommunications, airports, land transportation, mail delivery, banks, real estate and land records. The state bureaucracy had been wiped out and had to be built up, from the lowest level to the highest. The people with business experience, largely ethnic Chinese from Indonesia, had left the country. The legislation necessary for attracting the necessary foreign investment was also lacking. Timor-Leste did not have any functioning company law, no foreign investment law, no bankruptcy law and no efficient property rights law (which in turn opened the door for conflicting claims). The Indonesian legislative system had ceased to function and no domestic one had been built up.

Timor-Leste by and large lacked a functioning public administration when the country became independent. During the Indonesian occupation the government sector had been completely dominated by Indonesians, and they left in 1999. With the exodus of the trained 
officials followed the almost total destruction of all administrative systems and structures in the country. The consequence of this was that the United Nations Transitional Administration in East Timor (UNTAET) had to start building a new administration from scratch, in a situation where the number of qualified people was extremely low: a mission impossible indeed.

A conscious decision was made to limit the number of civil servants to about one-third of the figure during the Indonesian period. This gave a number of slightly over 9,000 in 2000/01, around 14,800 when defense and police forces were added. This target proved to be too optimistic, however. When the State of the Nation Report was drafted the number of positions actually filled amounted to slightly over 10,900, i.e. the shortfall was over 25 percent (Planning Commission, 2002, pp. 37-38). Training and capacity development proved to be difficult as well. When the lessons of the UNTAET experience were summarized in 2002, the following conclusions were drawn (UNTAET, 2002, p. xxviii):

UN benchmarks were used to set-up the administrative system but, in light of the situation in East Timor, those benchmarks may not have been pertinent. The UNTAET experience has proven again that having people with the right set of skills and technical knowledge is critical to the effectiveness and success of the mission. Having few but competent staff is preferable to having more staff but without the requisite skills. In East Timor, two types of people were needed - one group with the expertise to get the job done, and another with the know-how to train and develop capacities. These skill-sets, though not mutually exclusive, rarely reside within the same group. For UNTAET to be more effective, it might have required a different team of administrators who could deal with the sustainable development issues once the set-up team had completed its tasks. 
One serious obstacle to the development of a modern sector in Timor Leste is that the price level is artificially high, especially in the capital. There is a special reason for that: the presence of a large expatriate community of people - around 15,000 (World Bank, 2002, p. 17) - involved in the operations of the United Nations and other international agencies in Timor-Leste. This presence in fact meant that a dual economy had been created: on the one hand the traditional domestic subsistence economy, on the other hand an urban, aid-driven economy with a high purchasing power. The two were furthermore connected, in an unfortunate way. One would perhaps think that Timor-Leste would display one of the fundamental characteristics of some of the central models of dualistic economies (notably Lewis, 1954): an infinitely elastic supply of labor and its concomitant constant wage rate. This was, however, not the case (World Bank, 2002, pp. 17-18):

The large influx of international agencies, NGOs and other foreign employers - and the shortage of skilled local staff - resulted in an estimated quadrupling of wages, measured in US dollars. In the coffee industry, for example, unskilled farm labor earned the equivalent of \$0.90 per day in mid-1999 and now [2002] earns \$3.50. Civil service wages were set at rates starting at about $\$ 85$ per month, which was about three times the average in Indonesia [...] The ... [most] serious problem with relatively high public sector wages (at the lower grade levels) is their demonstration effect for the private sector.

Thus, there was a clear wage element in the inflation process.

The most important short-run obstacle to this creation is the weak legislative and institutional structure. An IMF mission visiting Timor-Leste in March 2005 identified the steps already taken to remedy this (International Monetary Fund, 2005, p. 12): 
- New land-lease legislation should encourage property rental;

- The new investment laws, despite potential drawbacks from the envisaged fiscal incentives, are a major step forward in setting up the broad legal framework needed to attract investment;

- The imminent establishment of a 'one-stop shop' for business registration under the new Investment and Export Promotion Agency is a positive sign;

- The prospective enactment of the insurance law should set the stage for the development of an insurance market, providing instruments for reducing investment risks; and

- The establishment of a regular dialogue between government and business to exchange views on solutions for the most urgent legal and administrative impediments to the development of private sector activity.

The mission also pointed to some additional reforms to be undertaken as quickly as possible (International Monetary Fund, 2005, p. 13):

- Additional steps to streamline business registration practices, reduce set-up costs and simplify interaction with the administration;

- Establishment of a comprehensive land-titling system, the absence of which hinders land improvement and limits the use of land as collateral;

- A regulatory framework for company incorporation, mediation and arbitration;

- The finalization of bankruptcy legislation to fill a regulatory vacuum on creditor rights in case of business solvency problems;

- Licensing of insurance companies; and 
- Renewed efforts to develop a strong and independent judiciary, given that a fair judicial system able to enforce contracts consistently is a primary requisite for private economic activity.

All these reforms fall into the area of legislation, and institution and administration building, and they can be undertaken by the government together with the parliament. All of them, however, are merely necessary, not sufficient, measures. Even with all of them in place, there is no guarantee that a viable private modern sector will be established. For this, incentives that will bring forth entrepreneurs who set up firms are needed as well. The most powerful of all incentives is the market. If a demand exists for a product that can be manufactured in TimorLeste, chances are that firms will come into existence as well.

Whether a market exists is, however, an open question. Timor-Leste has opted for a very open economy. With the exception of some selected items, like cigarettes and alcohol, a uniform ad-valorem tariff of 6 percent is levied on imports, and no quantitative import restrictions exist (International Monetary Fund, 2004, p. 49). This means that both internationally and in the domestic market, Timorese producers will be subject to competition - strong competition - since Timor is located in one of the economically most dynamic regions in the world: East Asia.

A manufacturing sector may be difficult to develop for yet another reason. The level of education is low in Timor-Leste (Lundahl and Sjöholm, 2005, pp. 18-24), so the supply of skilled workers is small. At the same time, the public sector is making strong efforts to build up capacity. As we have already seen, these efforts have not been completely successful, and there is still a shortfall. Virtually all the foreign donors are now making strong efforts to help the Timorese to close this gap. Funds are being put into capacity building to an increasing extent. This effort will continue for a number of years to come and this in turn has 
implications for the creation of a modern private sector. Skilled personnel will be drawn primarily into the public sector. The latter exists already and there are vacancies to be filled. The nascent private sector will have to compete with the government bureaucracy for people, and there will be an upward pressure on the skilled wage level, and the unskilled will have to continue to go into agriculture. The public sector may crowd out the private one.

There is also a somewhat more subtle mechanism that may come into play. The public administration on the one hand serves as a 'lubricant' for the private sector, by providing law and order, by building physical infrastructure, by providing education, etc. This serves to increase private production. But the public sector also competes with the private sector for labor, and this of course serves to lower private production. The optimal allocation of the labor force between public and private activities is when the marginal contribution to private production from the 'lubrication effect' equals the marginal loss of private production as workers leave the private sector to work in the public administration instead (Findlay and Wilson, 1987).

In the long run, the public sector is likely to complement the private one through the lubrication effect. In the short and medium term, the relation may, however, be a different one, with only weak lubrication and strong competition for workers, which acts as an obstacle to the creation and expansion of private modern-sector activities. In this sense, too many skilled employees may go into the public sector and too few into the private one - because the skilled wage level is inflated by the recruitment of a government bureaucracy. In another sense, however, the public sector may be too small. Public sector activities are likely to entail some economies of scale, in the provision of law and order, infrastructure etc.

This is illustrated in Figure 1. The marginal cost of providing public benefits increases at an increasing rate. Had no economies of scale been present, the marginal benefit curve would have been downward-sloping throughout. With economies of scale, however, 
there will be a rising segment as well. The marginal benefit curve rises, reaches a maximum and then falls when the economies of scale have been exhausted. Let us assume that the economy is in an initial equilibrium with a small public sector, equal to $\mathrm{P}_{1}$. Here the marginal benefit of expanding the sector is equal to the marginal cost of doing so. Moving to the right of $\mathrm{P}_{1}$, e.g. to $\mathrm{P}_{2}$, will not be meaningful, since in the interval $\mathrm{P}_{1} \mathrm{P}_{2}$ the marginal cost exceeds the marginal benefit. $\mathrm{P}_{1}$ is only a local optimum, however, not a global one, for if the expansion of the public sector continues beyond point B, where the two curves intersect each other, we get into a segment where the economies of scale are large enough to make the marginal benefit exceed the marginal cost, until we reach point $C$ where again equality obtains between the marginal benefit and the marginal cost, in the global optimum.

--Figure 1 about here--

What this means is that if the decision makers are myopic or the public sector cannot be expanded for some other reason, the economy may be stuck in the low-level equilibrium $\mathrm{P}_{1}$ where the lubrication effect on the private sector is too weak. This situation is quite likely to apply in Timor-Leste, where, so far, the build-up of the public sector has not been altogether successful (World Bank, 2005a, p. 19):

Capacity-building initiatives have often operated in the absence of a clear sectoral strategy and institutional framework, and without reference to the development and streamlining of systems and processes. In-line technical assistance was most often provided without careful succession planning to ensure that local staff acquired the qualifications needed to take over internationally staffed positions. Due to the emergency situation and the shortage of qualified national staff, international advisers 
tended to focus mainly on re-establishing administrative functions and performing line functions. As a result, the impact of these advisers on the capacity of their counterparts has been variable and highly dependent on the technical and inter-personal skills of advisers and advisees alike. Training programs have almost exclusively targeted the development of knowledge and skills, at the expense of critical guidance on leadership, management, attitudes and behaviors, and systems and processes. The lack of a systematic approach to capacity development has therefore left many institutions with limited capacity.

The result of this has been a budget execution rate that falls short of the approved expenditures. In 2002/03 it amounted to 95.3 percent and for 2003/04 the figure was 92.7 percent (Lundahl and Sjöholm 2005, p. 35). At the end of February 2005, 57 percent of the 2004/04 expenditures had been executed, against a targeted 67 percent, i.e. the execution rate was a mere 85 percent (World Bank, 2005a, p. 13). What this implies is that lubrication effect is likely to have been small, while at the same time the expansion of the public sector has served to increase skilled wages, and if this continues during the next few years as well, the net effect of public spending on private production may be small, negligible or in the worst case negative.

This presumption is borne out by the conclusions reached by the World Bank in its country assistance strategy for Timor-Leste for 2005-08. The two main conclusions drawn about the relations between the public and the private sector were (1) that the infrastructure is poorly developed and factor costs high and (2) that while good progress has been made on the completion of the regulatory framework of private business, the associated administrative procedures are both unclear and cumbersome (World Bank, 2005b, p. 14). The road network is extensive, but it is also in poor condition. Air transports to and from the country are 
expensive. The electricity supply is among the costliest in the world. In district capitals electricity is available for a few hours per night, and most of the countryside has no electricity at all. Phone calls cost 12-23 cents per minute as compared to 3-9 cents in Indonesia. The landline network does not extend outside the major towns, and mobile phone coverage in rural areas is only patchy. The wage level is several times the one prevailing in the rest of the region while the labor productivity remains low.

On the legal front several obstacles remain as well, in spite of some recent progress (World Bank, 2005b, p. 14):

The law on commercial societies, the insurance law, and the domestic and foreign investment laws have all been promulgated. Laws on payments and bankruptcy are currently under development. While this progress is laudable, in practice businesses face weak administration and rule of law. The process for business registration is complex and unclear. Customs procedures are lengthy, creating unnecessary administrative hurdles. Increasingly, businesses also complain of harassment and corruption. The justice system remains particularly weak with regard to the resolution of civil cases. At the end of 2004, the Court of Appeals alone had a backlog of 34 civil cases and had only ever resolved three. A framework law on land and property rights has been promulgated, as has a decree law on the leasing of Government property. The corresponding law on the leasing of private property is under consideration by Parliament, and laws on land dispute mediation, land rights and title restitution, and foreign owner compliance are in progress. Implementation of these laws will depend significantly on future progress in cadastral work and the registration of titles. 
Implementation will be a problem at least in the immediate future because of the large problems plaguing the justice sector (World Bank, 2005a, p. 8). It is thus obvious that the development of an efficient public sector has not moved very far beyond the mere beginning. Progress on his front is a priority also from the point of view of private production. The economy must be made to move out of the 'competitive' stage, where the two sectors appear as 'rivals', and into the ‘complementary' one.

\section{CONCLUSIONS}

Timor-Leste began its independence as one of the poorest nations in the world. Substantial progress has been made thereafter but the challenges for future development are numerous. Of special concern is the very high and seemingly increasing population growth. This, in combination with a relatively modest growth of GDP, means that per capita income is declining and that the extent of poverty presumably is increasing. For this situation to change, income opportunities other than those provided by subsistence agriculture are needed. Considering the low level of education and the keen competition for skilled personnel this, however, is difficult. So far, it seems that most skilled workers are being absorbed by the public sector and that this is pushing up the already high skilled wage level. That, in turn, affects the competitiveness of the private sector negatively and acts as an obstacle to the creation of employment opportunities outside agriculture. 


\section{REFERENCES}

Angeles, Gustavo, Guilkey, David K. and Mroz, Thomas A. (2005) The Effects of Education and Family Planning Programs on Fertility in Indonesia, Economic Development and Cultural Change, 54, pp. 165-201

Findlay, Ronald and Wilson, John D. (1987) The Political Economy of the Leviathan, in: Assaf Razin and Efraim Sadka (Eds) Economic Policy in Theory and Practice (London, Macmillan)

Hill, Hal and Saldanha, João M. (2001) East Timor: Development Challenges for the World's Newest Nation (Singapore: Institute for Southeast Asian Studies).

International Monetary Fund (2004) Democratic Republic of Timor-Leste: 2004 Article IV Consultation - Staff Report; Public Information Notice on the Executive Board Discussion; and Statement by the Executive Director for the Democratic Republic of Timor-Leste, IMF Country Report No. 04/321. October (Washington, D.C.:IMF)

International Monetary Fund (2005), Staff Report for the 2005 Article IV Consultation, 31 May. (Washington, D.C.: IMF)

Lundahl, Mats and Sjöholm, Fredrik (2005), Poverty and Development in Timor-Leste, Sida Country Economic Report 2005:3 (Stockholm: Sida)

Ministry of Health and National Statistics Office, ACIL Australia, University of Newcastle and the Australian National University (2004) Timor-Leste Demographic and Health Survey. Key Findings (Dili: Ministry of Health)

Planning Commission (2002) East Timor: State of the Nation Report, April. Dili

Shoesmith, Dennis (2003) Timor-Leste: Divided Leadership in a Semi-Presidentia System, Asian Survey, 43, pp.231-252.

UNDP (United Nations Development Programme) (2002) East Timor Human Development Report 2002. Ukun Rasik A'an/The Way Ahead (Dili: UNDP)

UTAET (United Nations Transitional Administration in East Timor) (2002) Debriefing and Lessons (Leiden: Martinus Nijhoff Publishers)

World Bank (2002) East Timor: Policy Challenges for a New Nation (Washington, D.C.: World Bank)

World Bank (2005a) Background Paper for the Timor-Leste and Development Partners Meeting 25-26 April 2005 (Washington, D.C.: World Bank)

World Bank (2005b) World Bank Country Assistance Strategy for Timor-Leste FY 06-08. Creating the Conditions for Sustainable Growth and Poverty Reduction. Report No. 32700TP. 11 August. (Washington, D.C.: World Bank) 
Figure 1: Economies of Scale in the Public Sector

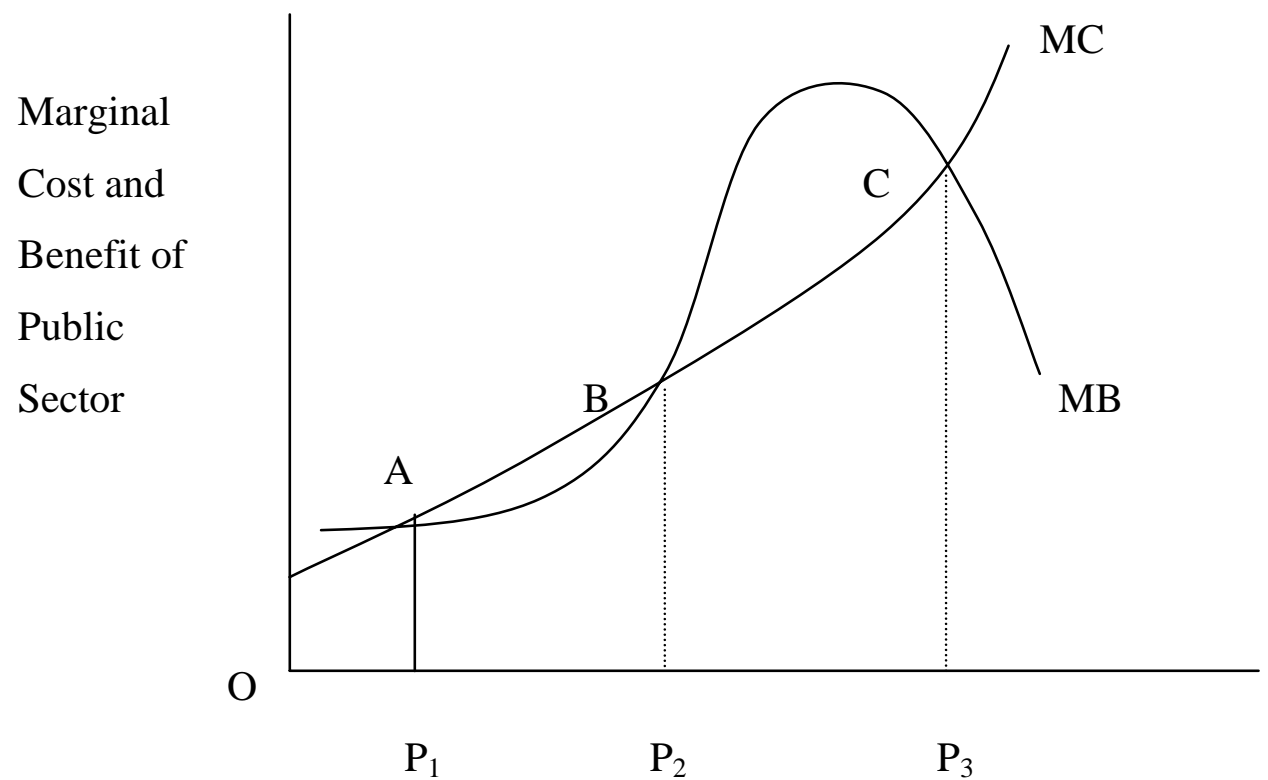

Size of Public Sector (P) 